\title{
A Corpus-based Study of the Chinese Translation for the Conditional Clause Patterns in International Legal Instruments*
}

\author{
HU Hong-ling \\ South China Business College, Guangdong University of Foreign Studies, Guangzhou, China
}

\begin{abstract}
The Chinese translation for international legal instruments is an indispensable part in national political and economic fields. Apart from legal terminology, the syntactical features of international legal instruments also deserve study. They are easy to be seen in the use of some typical sentence patterns, such as long and complex sentence structures, passive voice and provisos or conditional clauses. Based on the parallel English-Chinese international conventions, this paper mainly evaluates the current Chinese translation and summarizes the use frequency and translation strategies for the conditional clause patterns. From the perspective of memetics, sentence patterns can be units of imitation, and the summary of and comments on them and their Chinese translation will promote the transmission across culture and help a legal translator improve his/her expertise, which will eventually be good for successful cooperation in international business.
\end{abstract}

Keywords: legal translation, conditional clause patterns, memetics, parallel English-Chinese international conventions

\section{Introduction}

International legal instruments include international conventions and agreements, etc., which are binding at international law that are created and voluntarily agreed to by states (Cao, 2008, p. 135). With the acceleration of globalization, more and more countries signed and comply with international conventions so as to strengthen cooperation and connections with other countries. Accordingly, good translation of international legal instruments is an indispensable part in national political and economic fields, because it is directly related to the observance and implementation of the international conventions in the signatory countries. Apart from legal terminology, which is regarded as the most visible and striking linguistic feature of legal language as a technical language and also one of the major sources of difficulty in translating legal documents (Cao, 2008, p. 53), the syntactical features in legal documents should also be paid high attention to, for the long and complex sentence structures, passive voice and provisos or conditional clauses are very easy to be seen in legal documents. Due to the fact that many clauses, such as attributive clauses and adverbial clauses are used in a sentence to give an elaborate description of all the relevant conditions and circumstances, long and complicated

\footnotetext{
*Acknowledgements: The author wishes to acknowledge the fund from Guangdong Provincial Department of Education for the project she undertakes "Innovative Research on the Cultivation of Applied Business Translators under the Cooperative Education Model" (Project Code: 2015GXJK206), the support from Guangdong Philosophy and Social Science Fund for the project she undertakes "Research on the Theory and Practice of Memes of Legal Translation Under the Background of Running the Country by Law" (Project Code: GD15XWW14), and the Scientific Research Fund of South China Business College of Guangdong University of Foreign Studies for the project "Study on the Personality Characteristic of Memes of Legal Translation" (Project Code: $15-003 \mathrm{~A}$ ) in the writing up of this paper.

HU Hong-ling, Ph.D candidate, Lecturer, South China Business College, Guangdong University of Foreign Studies.
} 
syntactical structures are frequently used in legal documents, especially the conditional clauses. George Coode once pointed out in his book On Legislative Expression; or, The Language of The Written Law, the condition is that part of a legislative sentence which sets out what is to be done in order that the law may take effect.

\section{The Theory of Memes}

The concept of memes was first introduced by Dawkins in The Selfish Gene (1976). A meme is a unit of cultural transmission, or a unit of imitation. Examples of memes are tunes, ideas, catch-phrases, clothes fashions, ways of making pots or building arches (Chestman, 2012, p. 5). Just as genes propagate themselves in the gene pool by leaping from body to body via sperm or eggs, so memes propagate themselves in the meme pool by leaping from brain to brain via a process which, in the broad sense, can be called imitation (Dawkins, 1976, p. 206). That means all the things that can be imitated are memes. This includes all the words in your vocabulary, the stories you know, the skills and habits you have picked up from others and the games you like to play. It includes the songs you sing and the rules you obey (Blackmore, 1999, p. 6). Meme transmission within a culture takes place through imitation and of course also through language. But for a meme to be transmitted verbally across cultures, it needs a translation (Chestman, 2012, p. 7).

\section{Research Methodology and Questions}

\section{Corpus-based Approach in Translation Studies}

Nowadays, more and more scholars use the parallel English-Chinese texts to build bilingual corpora, no matter how simple or small they are, to help students compare the source and target language texts and enhance their translation ability by concluding some distinguished lexical or syntactical features. In fact, early in 1993 , Baker predicts enthusiastically: "[t]he profound effect that corpora will have on translation studies, in my view, will be a consequence of their enabling us to identify features of translated text which will help us understand what translation is and how it works" (Baker, 1993, pp. 233-259). Since then, the corpus approach has been applied in translation studies as a "viable and fruitful perspective" and "a novel and systematic way" of research which "addresses a variety of issues pertaining to theory, description, and the practice of translation". "Translator trainers have begun to design general and specialized corpora to aid the comprehension of source language texts and improve production skills" (Laviosa, 1998, pp. 474-479).

\section{The Design of English and Chinese Corpora}

For the purpose of research in this paper, major international conventions or agreements regulating international business relations such as CISG (United Nations Convention on Contracts for International Sale of Goods), TRIPs (Agreement on Trade-Related Aspects of Intellectual Property Rights), and PCPIP (Paris Convention on the Protection of Industrial Property) and their official Chinese versions are collected as mini database to analyze the use of typical conditional clause patterns in international legal instruments so that translators can identify the syntactical features of the source texts and summarize the translation strategies of the target texts. Thus, two corpora are built, namely, the International Legal Instruments Corpus, which consists of 3 major international commercial conventions or agreements, including CISG, TRIPs, and PCPIP; the Chinese Version of the International Legal Instruments Corpus (see Table 1).

\section{Research Questions}

The research in this paper focuses on answering the following three questions:

- What are the features of the typical conditional clause patterns? 
- What are the translation strategies of the Chinese translation for these patterns?

- What can be summarized as memes from the conditional clause patterns and their Chinese translation to help improve a legal translator's expertise?

Table 1

Conventions or Agreements Selected for Corpus of International Legal Instruments

\begin{tabular}{llllc}
\hline No. & Name of Conventions or Agreements & $\begin{array}{l}\text { Words in English } \\
\text { Version }\end{array}$ & $\begin{array}{l}\text { Characters in } \\
\text { Chinese Version }\end{array}$ & $\begin{array}{l}\text { Ratified by } \\
\text { (countries) }\end{array}$ \\
\hline 1 & $\begin{array}{l}\text { United Nations Convention on Contracts for International } \\
\text { Sale of Goods (CISG for short) }\end{array}$ & 10,149 & 20,936 & 80 \\
2 & $\begin{array}{l}\text { Agreement on Trade-Related Aspects of Intellectual } \\
\text { Property Rights (TRIPs for short) }\end{array}$ & 13,004 & 19,105 & 116 \\
3 & $\begin{array}{l}\text { Paris Convention on the Protection of Industrial Property } \\
\text { (PCPIP for short) }\end{array}$ & 2,734 & 4,050 & 176 \\
\hline
\end{tabular}

\section{Discussion}

\section{Reasons for Choosing International Commercial Conventions or Agreements}

CISG, TRIPs, and PCPIP are chosen for this research because they are the international conventions or agreements widely approved and ratified by countries in the world many years ago to promote the business cooperation and economic development. For example, PCPIP (Paris Convention on the Protection of Industrial Property) was signed in Paris, France, on 20th March 1883, and still in force today. TRIPs (Agreement on Trade-Related Aspects of Intellectual Property Rights) has been ratified by more than half of the countries all over the world. They can be regarded as very typical international legal instruments, a study of the conditional clause patterns in which would be of some demonstration significance.

\section{Features of the Conditional Clause Patterns in the English Corpus}

According to Li Kexing from the Hongkong Polytechnic University of China, altogether there are eight words or phrases which introduce adverbial clauses expressing condition in English legal documents, including "if", "where", "when", "in case", "in the event that", "should", "provided that", and "providing" (LI, 2008, pp. 71-77). It is well known that, generally, "when" is used to ask questions about time or used to introduce a clause which specifies or refers to the time at which something happens. "Where" is often used to ask questions about the place something is in, or is coming from or going to, or used to introduce a clause in which you mention the place in which something is situated or happens (YU, 2011, p. 3035). However, in legal instruments, clauses introduced by "when" and "where" do not express time and place any more, but conditions. The above mentioned eight words or phrases will be analyzed in the following Tables (see Tables 2, 3, 4, 5, and 6) based on the statistics from the English corpus.

"If" appears 126 times in CISG, 21 times in TRIPs, and 31 times in PCPIP, totally 178 times in 3 international legal instruments. Based on the statistics from the two corpora, "if" is the most used conjunction compared to the other seven words or phrases. When "if" introduces a conditional clause, it is often translated into “如果”, “如若”, and “如” in Chinese, all of which introduce the circumstances in which a situation might happen. The meaning of "if" in legal English is almost the same as that in daily English.

The use frequency of "where" ranks the second among the eight words or phrases which introduce adverbial clauses expressing condition. Generally, "where" can be used as a conjunction as well as a relative pronoun in daily English, both related to place. But when "where" used in legal meaning, it has nothing to do with place at all, but introducing a conditional clause, explaining the circumstances in which an event or 
situation might happen. Even in legal instruments, "where" can be used both in daily meaning and legal meaning, but more often in legal meaning. When used in legal meaning, “where” can be translated into “如果”, the same meaning as that of "if". Sometimes "where" can be interchanged with "if", but "where" seems more formal than "if". Also, it does not mean that "where" can be translated into “如果” in any Chinese versions of legal instruments, because in Chinese Criminal Law, the structure of "....... 的" is frequently used to introduce a condition, and the structure of “凡......" is often used in legal documents in Hongkong of China.

Table 2

Statistics of "if" and its Chinese Translation in the Corpora

\begin{tabular}{|l|l|}
\hline Word or phrase & if \\
\hline Part(s) of Speech & Conj. \\
\hline Meaning in daily English & $\begin{array}{l}\text { Used in conditional sentences to introduce the circumstances in } \\
\text { which an event or situation might happen,might be happening or } \\
\text { might have happened }\end{array}$ \\
\hline Meaning in legal English & Same as above \\
\hline Use frequency & 126 times in CISG, 21 in TRIPs, 31 in PCPIP, totally 178 \\
\hline Typical Examples & Chinese Translations \\
\hline $\begin{array}{l}\text { If the seller is not bound to deliver the goods at any other } \\
\text { particular place,... }\end{array}$ & 如果卖方没有义务要在任何其它特定地点交付货物, ....... \\
\hline $\begin{array}{l}\text { If } \text { they do not significantly differ from known designs or } \\
\text { combinations of known design features,... }\end{array}$ & 如果它们不显著区别于已知的设计或已知设计的特征的组 \\
\hline $\begin{array}{l}\text { If } \text { the subject matter of a patent is a process for obtaining a } \\
\text { product,... }\end{array}$ & 如若一项专利的客体是获得一种产品的方法,....... \\
\hline $\begin{array}{l}\text { If the right holder fails to pursue the right of action within a } \\
\text { reasonable period of time,... }\end{array}$ & 如若权利持有人在一合理期限内未行使诉讼权, ....... \\
\hline If Articles 13 to 17 do not enter into force on that date,... & 如第十三条至第十七条在上述日期侗未发生效力,...... \\
\hline
\end{tabular}

Table 3

Statistics of "Where" and its Chinese Translation in the Corpora

\begin{tabular}{|c|c|}
\hline Word or phrase & Where \\
\hline Part(s) of Speech & Conj.; relative pronoun \\
\hline Meaning in daily English (DM for short) & $\begin{array}{l}\text { Used to ask questions about place or situation; or to introduce a } \\
\text { clause in which you mention the place or situation; or to } \\
\text { introduce a clause that contrasts with the other parts of the } \\
\text { sentence }\end{array}$ \\
\hline Meaning in legal English (LM for short) & $\begin{array}{l}\text { = if (can be interchanged with "if") } \\
\text { Used in conditional sentences to introduce the circumstances in } \\
\text { which an event or situation might happen, might be happening } \\
\text { or might have happened }\end{array}$ \\
\hline Use frequency & 19 times in CISG, 48 in TRIPs, 18 in PCPIP, totally 85 \\
\hline Typical Examples & Chinese Translations \\
\hline $\begin{array}{l}\text { Where a contract has been validly concluded but does not } \\
\text { expressly or implicitly fix or make provision for determining } \\
\text { the price, the parties are considered, in the absence of any } \\
\text { indication to the contrary, to have impliedly made reference to } \\
\text { the price generally charged at the time of the conclusion of the } \\
\text { contract for such goods sold under comparable circumstances in } \\
\text { the trade concerned (LM) }\end{array}$ & $\begin{array}{l}\text { 如果合同已有效订立，但没有明示或暗示地规定价格或规定 } \\
\text { 如何确定价格，在没有任何相反表示的情况下，双方当事人 } \\
\text { 应视为已默示地引用订立合同时此种货物在有关贸易的类 } \\
\text { 似情况下销售的通常价格。 } \\
\text { 至。 }\end{array}$ \\
\hline $\begin{array}{l}\text { In other cases - in placing the goods at the buyer's disposal at } \\
\text { the place where the seller had his place of business at the time } \\
\text { of the conclusion of the contract (DM) }\end{array}$ & $\begin{array}{l}\text { 在其它情况下,卖方应在他于订立合同时的营业地把货物交 } \\
\text { 给买方处置。 }\end{array}$ \\
\hline
\end{tabular}


Table 4

Statistics of "Provided that" and Its Chinese Translation in the Corpora

\begin{tabular}{|l|l|}
\hline Word or phrase & Provided that \\
\hline Part(s) of Speech & Conj. \\
\hline Meaning in daily English & $\begin{array}{l}\text { =provided; providing. } \\
\text { If people say that something will happen provided that } \\
\text { something else happens, they mean that the first thing will } \\
\text { happen only if the second thing also happens. }\end{array}$ \\
\hline Meaning in legal English & Same as above \\
\hline Use frequency & 9 times in CISG, 21 in TRIPs, 9 in PCPIP, totally 39 \\
\hline Typical Examples & Chinese Translations \\
\hline $\begin{array}{l}\text { The acceptance is effective at the moment the act is performed, 接受于该项行为做出时生效, 但该项行为必须在上一款所规 } \\
\text { provided that the act is performed within the period of time laid } \\
\text { down in the preceding paragraph. }\end{array}$ & 定的期间内做出。 \\
\hline $\begin{array}{l}\text { Consequently, they shall have the same protection as the latter, } \\
\text { and the same legal remedy against any infringement of their } \\
\text { rights, provided that the conditions and formalities imposed } \\
\text { upon nationals are complied with. }\end{array}$ & \begin{tabular}{l} 
因同样的法律上的救济手段, 但是以他们遵守对国民规定和国和手续为限。 \\
\hline $\begin{array}{l}\text { it may maintain such system provided that the commercial } \\
\text { rental of phonograms is not giving rise to the material impairment } \\
\text { of the exclusive rights of reproduction of right holders. }\end{array}$
\end{tabular} \\
\hline
\end{tabular}

"Provided that" appears altogether 39 times in the International Legal Instruments Corpus. Its use frequency ranks the third among the eight words or phrases which introduce adverbial clauses expressing condition. Although "provided that" can be interchanged with "providing" and "provided", "providing" and "provided" never appears in the 3 international legal instruments chosen to build the corpus. The Chinese translations for “Provided that” include “但”, “但是”, and “只要”, which all means that the clause introduced by "provided that" is the condition of another thing. There is no difference between the legal meaning and its daily meaning.

Table 5

Statistics of "Unless" and Its Chinese Translation in the Corpora

\begin{tabular}{|c|c|}
\hline Word or phrase & Unless \\
\hline Part(s) of Speech & Conj. \\
\hline Meaning in daily English & $\begin{array}{l}\text { Used to say that something can only happen or be true in a } \\
\text { particular situation }\end{array}$ \\
\hline Meaning in legal English & Same as above \\
\hline Use frequency & 23 times in CISG, 6 in TRIPs, 7 in PCPIP, totally 36 \\
\hline Typical Examples & Chinese Translations \\
\hline $\begin{array}{l}\text { Contracts for the supply of goods to be manufactured or } \\
\text { produced are to be considered sales unless the party who orders } \\
\text { the goods undertakes to supply a substantial part of the } \\
\text { materials necessary for such manufacture or production. }\end{array}$ & $\begin{array}{l}\text { 供应佮待制造或生产的货物的合同应视为销售合同, 除非订 } \\
\text { 购货物的当事人保证供应这种制造或生产所需的大部分重 } \\
\text { 要材料。 }\end{array}$ \\
\hline $\begin{array}{l}\text { Unless it has already done so, each country shall indicate, } \\
\text { concurrently with depositing its instrument of ratification or } \\
\text { accession, the class to which it wishes to belong. }\end{array}$ & $\begin{array}{l}\text { 除已经指定等级外，每一国家应在交存批准书或加入书的同 } \\
\text { 时,表明自己愿属哪一等级。 }\end{array}$ \\
\hline $\begin{array}{l}\text { The procedure shall provide a means to identify and protect } \\
\text { confidential information, unless this would be contrary to } \\
\text { existing constitutional requirements. }\end{array}$ & $\begin{array}{l}\text { 该程序应提供一种识别和保护机密信息的办法, 除非这违反 } \\
\text { 现行宪法的要求。 }\end{array}$ \\
\hline
\end{tabular}


"Unless" appears totally 36 times in the International Legal Instruments Corpus. Its use frequency ranks the fourth among the eight words or phrases which introduce adverbial clauses expressing condition. It can be translated into “除非” and “除”, which all means that the condition in a clause introduced by "unless” is the only one for an event not to take place or a statement not to be true. The meaning of "unless" in legal English is the same as that in daily English.

Table 6

Statistics of "When" and Its Chinese Translation in the Corpora

\begin{tabular}{|c|c|}
\hline Word or phrase & When \\
\hline Part(s) of Speech & Conj. \\
\hline Meaning in daily English (DM for short) & $\begin{array}{l}\text { Used to ask questions about time; or to introduce a clause in } \\
\text { which you mention something which happens at some point } \\
\text { during an activity; or to introduce a clause which specifies or } \\
\text { refers to the time at which something happens; or to introduce a } \\
\text { clause where you mention the circumstances under which the } \\
\text { event in the main clause happened or will happen. }\end{array}$ \\
\hline Meaning in legal English (LM for short) & $\begin{array}{l}\text { = if (can be interchanged with "if") } \\
\text { Used in conditional sentences to introduce the circumstances in } \\
\text { which an event or situation might happen. }\end{array}$ \\
\hline Use frequency & 16 times in CISG, 10 in TRIPs, 8 in PCPIP, totally 34 \\
\hline Typical Examples & Chinese Translations \\
\hline $\begin{array}{l}\text { No period of grace may be granted to the seller by a court or } \\
\text { arbitral tribunal when the buyer resorts to a remedy for breach } \\
\text { of contract (LM) }\end{array}$ & $\begin{array}{l}\text { 如果买方对违反合同采取某种补救办法, 法院或仲裁庭不得 } \\
\text { 给予卖方宽限期。 }\end{array}$ \\
\hline An offer becomes effective when it reaches the offeree (DM) & 发价于送达被发价人时生效。 \\
\hline
\end{tabular}

"When" appears totally 34 times in the International Legal Instruments Corpus, but it is used both in daily meaning and legal meaning. Its legal meaning can be translated into “如果”, “凡.....”, and “......的”, the same Chinese translation as that for "if" and "where". Its daily meaning in a legal instrument can be translated into “......时”, referring to the time at which something happens. Although the Chinese translation for "if", "where", and "when" can be the same, it does not mean that the three words may replace each other in English legal instruments, because "where" and "when" are more formal than "if", and also the legal meaning of "when" implies an event or situation might happen at SOMETIME in the future.

According to Li Kexing, "if", "where", "when", "in case", "in the event that", "should", "provided that" and "providing" are the eight words or phrases which are most frequently used as conjunctions to introduce conditional clauses in English legal documents. However, the statistics from the International Legal Instruments Corpus consisting of 3 major international commercial conventions or agreements shows that "in case", "in the event that", and "should" are never used.

\section{Learning and Translation Strategies for the Conditional Clause Patterns}

The five tables above show clearly that, among eight words or phrases which usually introduce conditional clauses in English legal documents, "if" is used of the highest frequency, "where" and "when" are used both in daily meaning and legal meaning even in international legal instruments, and the Chinese translation for "if", "where" and "when" can be the same. The legal meaning of "if" is exactly the same as its daily meaning, but the legal meaning of "where" is totally different from its daily meaning. For "when", the legal meaning has some sort of connection with its daily meaning although the Chinese translations for its two kinds of meanings are just like apples and pears. 
Based on the statistics, analysis of use frequency and Chinese translations of the conditional clause patterns, the learning and translation strategies can be summarized as follows:

Firstly, since a conditional clause is regarded as an indispensable part in a legal sentence, this syntactical feature itself can be seen as a meme to be stored by legal translators in brains to influence their acts, so that operative analysis of legal sentences can be conducted accordingly.

Secondly, according to memetics, all the things that can be imitated are memes, so the words and phrases like "if", "where", "when", "unless", and "provided that" which are used to introduce conditional clauses in legal sentences are memes, too. They can be passed from one person to another to help them not only understand this kind of sentences in legal instruments, but also write similar clauses.

Moreover, even the translation strategies are memes. Such as "if", "where" and "when" are often translated into the structure of "....... 的” or “凡......" and vice versa. These memes of translation strategies can be easily used in the translation of Chinese Criminal Law, in which hundreds of sentences contain the structure of “....... 的” to set out the circumstances or occasions to which the law is confined.

Fourthly, meme transmission within a culture takes place through imitation and language, but for memes to be transmitted across cultures, it needs a translation. Before translating, legal translators should fully understand the logical meaning of the conditional clauses. A good understanding of legal sentences is the prerequisite of good translation and enforcement of law, because the life of law lies in its effectiveness and enforcement. So, beginners of legal translation must study English language and English law as well, to become "infected", store them in brain and dispose all the memes to improve his/her translation expertise, and be ready to transmit them across culture.

\section{Conclusion}

Good translation of international legal instruments will undoubtedly contribute to the effective enforcement of international law in signatory countries. The study of the Chinese translation for the conditional clause patterns in legal documents based on the parallel English-Chinese international conventions can help legal translators learn a new and systematic way of research in translation practice and address the issue of how to translating typical sentence patterns. But Corpora are just databases of limited material, and they can not cover all the legal instruments. So the statistics and use analysis of the instruments in a corpus can only explain the features of conditional clause patterns to a certain extent. However, the corpus approach can be applied in further translation studies to help learners recognize a kind of facts, acquire the rules of translation, and improve the quality of translation in the long run. The theory of memes tells us that anything can be a unit of imitation. So, the facts of syntactical features, such as the fact that conditional clauses are easy to be seen in legal documents, the words or phrases that are frequently used to introduce conditional clauses, and the summarized rules of translation, as well as the spirits of law themselves can be memes to be passed through imitation within a culture or across cultures.

\section{References}

Baker, M. (1993). Corpus linguistics and translation studies-implications and applications. In B. Mona, F. Gill, \& T. B. Elena (Eds.), Text and technology - In honour of John Sinclair (pp. 233-250). Amsterdam: John Benjamins.

Blackmore, S. (1999). The meme machine. Oxford: Oxford University Press.

Cao, D. (2008). Translating law. Shanghai: Shanghai Foreign Language Education Press. 
Chestman, A. (2012). Memes of translation: The spread of ideas in translation theory. Shanghai: Shanghai Foreign Language Education Press.

Dawkins, R. (1976). The selfish gene. Oxford: Oxford University Press.

Laviosa, S. (1998). The corpus-based approach: A new paradigm in translation studies. Meta: Translators' Journal, 43(4), 474-479.

LI, K. X. (2008). Composing and translating conditional clauses in legal texts. Chinese Translators Journal, 4, 71-77.

YU, C. C. (2011). Collins COBUILD advanced learner's English-Chinese dictionary. Foreign Language Teaching and Learning Press. 